\title{
Altered rumen fermentation patterns in lactating dairy cows supplemented with phytochemicals improve milk production and efficiency
}

\author{
R. C. B. Grazziotin, ${ }^{1}$ J. Halfen,,${ }^{1,2}$ ๑ F. Rosa, ${ }^{1}$ E. Schmitt, ${ }^{2}$ J. L. Anderson, ${ }^{1}$ (1) V. Ballard, ${ }^{3}$ and J. S. Osorio ${ }^{1 *}$ (1) \\ ${ }^{1}$ Department of Dairy and Food Sciences, South Dakota State University, Brookings 57007 \\ ${ }^{2}$ Núcleo de Ensino, Pesquisa e Extensão em Pecuaria, Departamento de Clínica Veterinaria, Programa de Pós-Graduação em Zootecnia, \\ Universidade Federal de Pelotas, 96160-000 Pelotas, RS, Brazil \\ ${ }^{3}$ Groupe CCPA (Conseils et Compétences en Productions Animales), ZA Nord Est du Bois de Teillay, 35150 Janzé, France
}

\begin{abstract}
Tannins and other phytochemicals are known to improve RUP in the diet by binding protein and then limiting ruminal degradation, which may improve milk yield and milk protein synthesis. The objective of this study was to evaluate the effects of dietary phytochemicals (tannins and Capsicum species) as rumen modifiers on production parameters and milk efficiency in dairy cows. Twenty-four multiparous Holstein cows (96 $\pm 16 \mathrm{~d}$ in milk; mean \pm standard deviation) were used in a replicated $3 \times 3$ Latin square design balanced to measure carryover effects. Cows were blocked according to days in milk, milk production, and body weight and randomly assigned to 1 of 3 groups $(n=8 /$ group). Each group was assigned to a unique treatment sequence across the 3 periods in the Latin square. The experiment consisted of a 14-d covariate period and three 30-d treatment periods. Cows received a basal diet supplemented with soybean meal pellets (SB) as the control diet, phytochemicals (RUM; Rumiviv, CCPA, Janzé, France) pelleted with soybean meal, or expeller soybean meal (ESBM; SoyPlus, West Central Soy, Ralston, IA). Milk production and dry matter intake during the last $4 \mathrm{~d}$ of each period were used for statistical analysis. Blood and rumen fluid samples were collected on d 27 of each period. Rumen fluid was analyzed for ammonia $\mathrm{N}$ and volatile fatty acids as well as ruminal bacteria via quantitative PCR amplification of $16 \mathrm{~S}$ ribosomal DNA genes. Greater milk yield (37.9 vs. $36 \mathrm{~kg} / \mathrm{d}$ ), energy-corrected milk (39.7 vs $37.1 \mathrm{~kg} / \mathrm{d}$ ), and protein yield (1.15 vs. $1.08 \mathrm{~kg} / \mathrm{d}$ ) were observed in RUM compared with SB, but these parameters were similar between RUM and ESBM. Concentrations of total volatile fatty acids (118.1 vs. $101.5 \mathrm{mM}$ ) were greater in RUM in comparison to SB and ESBM diets.
\end{abstract}

Received May 21, 2019.

Accepted September 20, 2019.

*Corresponding author: johan.osorio@sdstate.edu
Cows fed RUM had greater $\beta$-hydroxybutyrate (0.49 vs. $0.42 \mathrm{mmol} / \mathrm{L}$ ) than SB and ESBM. Selenomonas ruminantium, Succinimonas amylolytica, and Streptococcus bovis in rumen fluid were lower in RUM fed cows in comparison to SB and ESBM. Increased total volatile fatty acids and lower ruminal abundance of bacteria associated with low feed efficiency in RUM cows can partially explain the improvements observed in milk yield and milk efficiency. Overall, these data suggest that feeding a combination of tannin mixture and Capsicum can significantly affect rumen fermentation characteristics via partial manipulation of rumen microbiota, and these effects were reflected in improved milk production and efficiency.

Key words: phytochemical, rumen-degradable protein, microbiota

\section{INTRODUCTION}

The continuously narrowing gap between feed costs and milk prices in the dairy industry underscores the need to improve and maintain milk efficiency (i.e., amount of milk produced per $\mathrm{kg}$ of feed provided) in dairy farms (Potts et al., 2017). Dietary protein or CP is an essential nutrient in dairy cow rations and plays a significant role in the improvement of milk efficiency (Huhtanen and Hristov, 2009). Therefore, the adequate supply of CP and particularly MP to meet the cow requirements can significantly improve the economic return in a dairy farm operation (Schwab and Broderick, 2017). Metabolizable protein is the true protein digested postruminally originating from rumen microbial protein and RUP, and contains the AA absorbed by the intestine.

Plant-derived bioactive compounds (i.e., phytochemicals) have shown a variety of antimicrobial properties in ruminants as well as a great potential to modify rumen characteristics (Calsamiglia et al., 2007; Oh et al., 2017c). The latter has been observed in phytochemicals such as tannins, with the specific effect of improving milk efficiency and $\mathrm{N}$ utilization in lactation dairy cows 
(Frutos et al., 2004). Tannins are naturally occurring plant polyphenols that are classified as hydrolyzable or condensed and can bind dietary protein through hydrogen bonds, forming a tannin-protein complex. This complex is stable at ruminal $\mathrm{pH}(5.0-7.0)$ and consequently decreases rumen microbial degradation of proteins, and this complex is dissociated in the low $\mathrm{pH}$ environment of the abomasum (Frutos et al., 2004). Therefore, tannins have the potential to increase the RUP in a diet, and if combined with high-quality protein containing a significant amount of limiting AA such as Met and Lys, this could lead to an improvement in $\mathrm{N}$ efficiency and milk production by increasing the flow of an adequate supply of AA to the small intestine.

Capsicum species are flowering plants that contain capsaicinoids as their active compound, and such compounds has been observed to increased feed intake due to its pungency as well as modify rumen fermentation characteristics (Calsamiglia et al., 2007; RodriguezPrado et al., 2012). These rumen modifications include greater total VFA and propionate concentration (Cardozo et al., 2005). These effects by Capsicum species can be partially associated with their antimicrobial properties observed in vitro against Escherichia coli, Staphylococcus aureus, and Streptococcus pyogenes (alDelaimy and Ali, 1970; Cichewicz and Thorpe, 1996), and in vivo against Prevotella species (Oh et al., 2015).

Based on the previous research in ruminants, we hypothesized that using a combination of phytochemicals such as tannins and Capsicum will improve milk efficiency and milk protein in mid-lactation dairy cows by protecting dietary protein from ruminal degradation and consequently increasing dietary RUP while modifying rumen fermentation through inhibition of specific rumen microbial populations such as Streptococcus and Prevotella species. The objective of the study was to compare the combined effects of dietary phytochemicals including tannins and Capsicum as rumen modifiers to protect dietary protein from ruminal degradation against a known source of dietary RUP as expeller soybean meal (ESBM) fed to mid-lactation dairy cows.

\section{MATERIALS AND METHODS}

\section{Animal Housing and Care}

All experimental procedures were approved by the Institutional Animal Care and Use Committee at the South Dakota State University (protocol no. 17-010A). Cows were housed in a ventilated enclosed barn with access to mattress freestalls during the entire experiment. Cows were fed once daily at $0530 \mathrm{~h}$ using electronic admission gates with individual transponders
(American Calan, Northwood, NH). Feed offered was adjusted daily to achieve 5 to $10 \%$ refusal.

\section{Design and Treatment Diets}

Twenty-four multiparous Holstein cows $(96 \pm 16$ $\mathrm{DIM}$; mean $\pm \mathrm{SD}$ ) were used in a $3 \times 3$ replicated Latin square design balanced to measure carryover effects. Therefore, treatments were arranged so that the carryover effects could be tested. Cows were blocked according to DIM, milk production, and BW and randomly assigned to 1 of 3 groups ( $n=8 /$ group). And, each group was assigned to a unique treatment sequence across the 3 periods in the Latin square. The experiment lasted $104 \mathrm{~d}$ and consisted of a 14-d adaptation period before the start of the study (covariate period) and three $30-\mathrm{d}$ treatment periods. During the adaptation period, cows were fed a control diet, and baseline values were obtained for all variables. The dietary treatments consisted of a basal diet supplemented with soybean meal pellets (SB) as the control diet, phytochemicals [Rumiviv (RUM); CCPA, Janze, France] pelleted with soybean meal, or ESBM (SoyPlus, West Central Soy, Ralston, IA) as a source of RUP. The 3 groups of cows were switched through all 3 treatments in a 3 $\times 3$ Latin square design. The ingredient and nutrient composition of the diets fed as TMR are described in Table 1. Diets were formulated using the Spartan Dairy Ration Evaluator 3.0 (Michigan State University, East Lansing; https://www.canr.msu.edu/spartandairy/) to meet requirements of the average cow in the group according to the NRC (2001).

The pellets for the treatments SB and RUM were made from the same batch of soybean meal (Pipestone Grain Company, Pipestone, MN), and while SB pellets contained soybean meal only, RUM pellets contained soybean meal and phytochemicals at a $1.5 \%$ inclusion rate, which represented $0.06 \%$ inclusion rate of phytochemicals in the total diet DM. The Rumiviv test product (CCPA, Janze, France) contained phytochemicals including a tannin extract mixture from quebracho (condensed) and quercus (hydrolyzable) trees as well as Capsicum, and small amounts of xylose and trace minerals in sulfate forms (Fe, $\mathrm{Zn}$, and $\mathrm{Mn}$ ), which may improve the effects of these phytochemicals. Half of the daily dose of SB, RUM, and ESBM was top-dressed over the TMR after each milking.

\section{Data and Sample Collection}

Samples and data were collected during the last $4 \mathrm{~d}$ of the adaptation period (d 11 to 14 ) and subsequent treatment periods (d 27 to 30 ). Individual cow BW and BCS were recorded on 11 and $27 \mathrm{~d}$ of the adapta- 
Table 1. Ingredient and nutrient composition for a basal diet supplemented with soybean meal (SB), phytochemicals (RUM), and expeller soybean meal (ESBM)

\begin{tabular}{|c|c|c|c|}
\hline \multirow[b]{2}{*}{ Component } & \multicolumn{3}{|c|}{ Treatment } \\
\hline & SB & RUM & ESBM \\
\hline \multicolumn{4}{|l|}{ Ingredient, ${ }^{1} \% \mathrm{DM}$} \\
\hline Alfalfa hay & 8.47 & 8.47 & 8.44 \\
\hline Alfalfa haylage & 19.38 & 19.38 & 19.29 \\
\hline Corn silage & 33.20 & 33.20 & 33.05 \\
\hline Cottonseed & 6.71 & 6.71 & 6.68 \\
\hline Straw & 3.61 & 3.61 & 3.59 \\
\hline Calcium phosphate & 0.09 & 0.09 & 0.09 \\
\hline Distillers grains, dry & 1.89 & 1.89 & 1.88 \\
\hline Corn, fine & 15.64 & 15.64 & 15.57 \\
\hline Rumen-inert fat ${ }^{2}$ & 0.85 & 0.85 & 0.85 \\
\hline Limestone $\mathrm{Ca}$ & 0.71 & 0.71 & 0.71 \\
\hline Magnesium oxide & 0.14 & 0.14 & 0.14 \\
\hline Salt & 0.30 & 0.30 & 0.30 \\
\hline Binder & 0.03 & 0.03 & 0.03 \\
\hline Sodium bicarbonate & 0.71 & 0.71 & 0.71 \\
\hline Urea $281 \%$ CP & 0.31 & 0.31 & 0.31 \\
\hline Vitamin E & 0.03 & 0.03 & 0.03 \\
\hline JPW Dairy Vitamin Premix ${ }^{3}$ & 0.07 & 0.07 & 0.07 \\
\hline JPW Dairy TM Premix ${ }^{4}$ & 0.07 & 0.07 & 0.07 \\
\hline DV Nutritek & 0.06 & 0.06 & 0.06 \\
\hline Biotin 1\% & 0.005 & 0.005 & 0.005 \\
\hline Soybean hulls & 3.56 & 3.56 & 3.54 \\
\hline Soybean meal & 4.16 & - & - \\
\hline Phytochemicals $^{5}$ & - & 4.16 & - \\
\hline ESBM & - & - & 4.59 \\
\hline \multicolumn{4}{|l|}{ Chemical analysis } \\
\hline $\mathrm{NE}_{\mathrm{L}}{ }^{6} \mathrm{Mcal} / \mathrm{kg}$ of DM & 1.48 & 1.48 & 1.48 \\
\hline $\mathrm{CP}, \% \mathrm{DM}$ & 16.2 & 16.2 & 16.0 \\
\hline OM, \% DM & 93.1 & 93.0 & 92.9 \\
\hline $\mathrm{NDF}, \% \mathrm{DM}$ & 35.7 & 37.0 & 34.6 \\
\hline $\mathrm{ADF}, \% \mathrm{DM}$ & 25.4 & 24.5 & 23.9 \\
\hline
\end{tabular}

${ }^{1}$ Ingredients included in the ration formulated by using Spartan Dairy Ration Evaluator 3.0 (Michigan State University, East Lansing).

${ }^{2}$ Energy Booster 100 (MSC, Carpentersville, IL).

${ }^{3}$ Contained: $25.8 \% \mathrm{Ca}$ (DM basis), $1,545 \mathrm{IU} / \mathrm{kg}$ vitamin A, $387 \mathrm{IU} / \mathrm{kg}$ vitamin D, and 4,826 IU/kg vitamin E (JPW Nutrition, Sioux Falls, $\mathrm{SD})$.

${ }^{4}$ Contained: $11.7 \%$ Ca (DM basis), 1.96\% S, 10,527 mg/kg Fe, 63,158 $\mathrm{mg} / \mathrm{kg} \mathrm{Zn}, 12,632 \mathrm{mg} / \mathrm{kg} \mathrm{Cu}, 63,158 \mathrm{mg} / \mathrm{kg} \mathrm{Mn}, 325 \mathrm{mg} / \mathrm{kg} \mathrm{Se}, 632$ $\mathrm{mg} / \mathrm{kg} \mathrm{Co}$, and $1,053 \mathrm{mg} / \mathrm{kg}$ I (JPW Nutrition).

${ }^{5}$ Pellet containing $1.5 \%$ of phytochemicals or $0.06 \%$ of total diet DM.

${ }^{6}$ Values are from Spartan Dairy 3 based on actual DMI for each treatment and chemical composition of feed ingredients (Michigan State University).

tion and treatment periods, respectively. Dry matter of individual feed ingredients was determined weekly, and diet was adjusted accordingly to maintain DM ratios of ingredients in the TMR. Samples of all diet ingredients and TMR were collected on the last $3 \mathrm{~d}$ of each period and stored at $-20^{\circ} \mathrm{C}$ until analyzed. Upon arrival of treatment supplements of soybean pellets, phytochemical pellets, and ESBM, $10 \%$ of all bags were sampled for each supplement. Composite samples of each treatment supplement (Supplemental Table S1; https://doi .org/10.3168/jds.2019-16996), as well as diet ingredi- ent and TMR per period (Table 1), were analyzed for contents of $\mathrm{DM}, \mathrm{CP}, \mathrm{NE}_{\mathrm{L}}, \mathrm{NDF}, \mathrm{ADF}$, using wet chemistry methods (Dairy One, Ithaca, NY; https:// dairyone.com/services/forage-laboratory-services/feed -composition-library/). Daily DMI and milk yield were recorded throughout the experiment, but only the last $4 \mathrm{~d}$ of each period were used for statistical analysis. During the last $3 \mathrm{~d}$ of each period, milk samples were collected at each milking, and a daily composite sample was prepared based on the proportion of milk yield at each milking. Milk samples were analyzed for content of fat, protein, lactose, SNF, MUN, and SCC using Fourier-transform infrared spectroscopy (Dairy One; Table 3).

Rumen fluid was sampled from 15 cows $(\mathrm{n}=5$ / group), on 11 and $27 \mathrm{~d}$ of the adaptation and treatment periods, respectively, via esophageal tubing at 3 $\mathrm{h}$ post-feeding. The esophageal tubing apparatus was assembled by coupling the esophageal tube to a metal strainer (Raun and Burroughs, 1962) on one end, and the other end connected to the opposite handle side of a manual vacuum pump (Med-Eze stomach pump, MAI Animal Health, Elmwood, WI). The rumen fluid sample was collected by passing the fluid through the pump's hollow shaft and into a plastic beaker. After discarding the first $200 \mathrm{~mL}$ of fluid to minimize saliva contamination, approximately $50 \mathrm{~mL}$ of rumen fluid was collected. Samples were immediately measured for $\mathrm{pH}$ using a $\mathrm{pH}$ meter (Waterproof $\mathrm{pH}$ Testr 30, Oakton Instruments, Vernon Hills, IL) and 2 aliquots $(10 \mathrm{~mL})$ were acidified with either $200 \mu \mathrm{L}$ of $50 \%$ sulfuric acid or $2 \mathrm{~mL}$ of $25 \%$ metaphosphoric acid and stored at $-20^{\circ} \mathrm{C}$ until analysis of ammonia $\mathrm{N}\left(\mathrm{NH}_{3}-\mathrm{N}\right)$ and VFA, respectively. Additionally, a rumen fluid sample $(2 \mathrm{~mL})$ was collected and immediately frozen in liquid nitrogen and stored at $-80^{\circ} \mathrm{C}$ until further DNA isolation, and relative abundance of bacterial species was analyzed via the quantitative PCR (qPCR) method (see below).

For analysis of total-tract digestibility, samples of TMR, individual orts, and fecal grabs were collected from each cow during the last $3 \mathrm{~d}$ of each period and stored at $-20^{\circ} \mathrm{C}$. Eight fecal grabs were collected every $6 \mathrm{~h}$ from 0600 to $1200 \mathrm{~h}$ and from 0900 to $0300 \mathrm{~h}$ on 29 and $30 \mathrm{~d}$, respectively, of each period. These samples were analyzed for DM, OM, CP, NDF, and ADF as previously described for feed samples. Acid detergent insoluble ash was used as an internal digestibility marker, as previously described in Manthey et al. (2016).

\section{Blood Biomarker Analyses}

Blood was sampled from the coccygeal vein before morning feeding on 11 and $27 \mathrm{~d}$ of the adaptation and 
treatment periods, respectively. Samples were collected into evacuated serum tubes (BD Vacutainer, Becton Dickinson and Co., Franklin Lakes, NJ) containing either clot activator or lithium heparin for serum or plasma, respectively. After blood collection, tubes with lithium heparin were placed on ice and tubes with clot activator were kept at $21^{\circ} \mathrm{C}$ until centrifugation $(\sim 30$ min). Serum and plasma were obtained by centrifugation at $1,900 \times g$ for $15 \mathrm{~min}$ at $4^{\circ} \mathrm{C}$. Aliquots of serum and plasma were frozen $\left(-80^{\circ} \mathrm{C}\right)$ until further analysis.

Blood samples were analyzed for nonesterified fatty acids, BHB, and creatinine using commercial kits in an autoanalyzer at the Animal Disease Research and Diagnostic Laboratory at South Dakota State University. Glucose concentration was measured using a commercial kit (catalog no. 99703001, Wako Chemicals Inc., Richmond, VA). The concentration of blood urea nitrogen was determined using diacetylmonoxime (catalog no. 0580250, Stanbio Laboratory, Boerne, TX).

\section{Ruminal Bacteria DNA Isolation and qPCR Amplification of $16 S$ rDNA Genes}

The relative abundance of 10 rumen bacterial species was determined using a previous protocol described by Abdelmegeid et al. (2018) with modifications. The DNA in rumen fluid was isolated using the QIAmp DNA mini kit (Qiagen, Hilden, Germany) with modifications. Briefly, $1 \mathrm{~mL}$ of rumen fluid was centrifuged at $12,000 \times g$ for $5 \mathrm{~min}$, and the supernatant was discarded after centrifugation. Then, the pellet was resuspended in $400 \mu \mathrm{L}$ of lysis buffer $\mathrm{AL}$ and vortex, followed by the addition of $40 \mu \mathrm{L}$ of Qiagen protease. The mixture was transferred to a 2-mL O-ring tube and 1 bead (Qiagen, $5 \mathrm{~mm}$ ) was added, before homogenization in a semi-automated beadbeater homogenizer (catalog no. 112011, Biospec Products, Bartlesville, OK) for 1 min. After homogenization, the subsequent steps were performed according to the manufacturer's procedures (Abdelmegeid et al., 2018). The DNA quantity and purity were confirmed using a NanoDrop spectrophotometer (ND 1000, NanoDrop Technologies Inc., Wilmington, DE). The extracted DNA was standardized to $8 \mathrm{ng} / \mu \mathrm{L}$ for $\mathrm{qPCR}$.

The primer sets used in this study has been previously reported and validated by Abdelmegeid et al. (2018). The qPCR analysis was performed using a $10 \mu \mathrm{L}$ of qPCR mixture containing $4 \mu \mathrm{L}$ of sample DNA, $5 \mu \mathrm{L}$ of $1 \times$ SYBR Green master mix (Applied Biosystems, Waltham, MA), $0.4 \mu \mathrm{L}$ of $10 \mu M$ each for forward and reverse primers, and $0.2 \mu \mathrm{L}$ of DNase-RNase-free water in a MicroAmp Optical 384-well reaction plate (Applied Biosystems). Each sample was run in triplicate, and a 6-point relative standard curve plus the nontemplate control were used. The 4-fold-dilution standard curve was made using standardized DNA from all samples. The qPCR reactions were performed in a QuantStudio 6 Flex Real-Time PCR System (Applied Biosystems) using the following conditions: $2 \mathrm{~min}$ at $50^{\circ} \mathrm{C}, 10 \mathrm{~min}$ at $95^{\circ} \mathrm{C}, 40$ cycles of $15 \mathrm{~s}$ at $95^{\circ} \mathrm{C}$, and $1 \mathrm{~min}$ annealing at $60^{\circ} \mathrm{C}$. This protocol was used for all primer sets with the exception of Eubacterium ruminantium primer, where a 1 min annealing at $56^{\circ} \mathrm{C}$ was used. Relative abundance of bacterial species was calculated using the geometrical mean of 2 universal primers (Maeda et al., 2003; Fliegerova et al., 2014) with the efficiency-corrected $\Delta$ CT method (Abdelmegeid et al., 2018). The relative abundance of each bacterial species is relative to the total bacteria abundance measured with these universal primers.

\section{Statistical Analysis}

Data were analyzed using the mixed model procedure of SAS 9.4 (SAS Institute Inc., Cary, NC) to account for the carryover effect by the following model:

$$
y_{i j k l m}=\mu+S_{i}+A_{(i) j}+P_{(i) k}+T_{l}+C_{m}+e_{(i j k) l},
$$

where $y_{i j k l m}$ is the observations for the dependent variables, $\mu$ is the general mean, $S_{i}$ is the fixed effect of the $i$ th treatment sequence, $A_{(i) j}$ is the random effect of the $j$ th cow in the $i$ th sequence, $P_{(i) k}$ is the fixed effect of the $k$ th period, $T_{l}$ is the fixed effect of the $l$ th treatment, $C_{m}$ is the fixed carryover effect from the previous period ( $C$ $=0$, if period $=1)$, and $e_{(i j k) l}$ is the random error. If the carryover effect was not detected $(P \geq 0.05)$, the $C_{m}$ was removed from the model. The qPCR data and milk SCC were log-transformed before statistical analysis. Least squares means separation was corrected using Tukey's test and statistical significance was declared at $P \leq 0.05$ and trends at $0.05<P \leq 0.10$.

\section{RESULTS}

\section{Ingredient and Nutrient Composition of Diets}

Ingredient and chemical composition of the treatment diets are presented in Table 1. Due to the evident differences in CP\% between ESBM and pellets from SB and RUM, the inclusion rate from ESBM was increased in the overall diet from 4.16 to $4.59 \%$ (Table 1). This adjustment to the ESBM diet seemed to have been sufficient to equalize the CP\% across diets, with ESBM diet having an overall $0.2 \%$ lower $\mathrm{CP}$. 
Table 2. Effects of supplementing dairy cows with soybean meal (SB), phytochemicals (RUM), and expeller soybean meal (ESBM) during mid-lactation on DMI, BW, and BCS

\begin{tabular}{|c|c|c|c|c|c|c|}
\hline \multirow[b]{2}{*}{ Item } & \multicolumn{3}{|c|}{ Treatment } & \multirow[b]{2}{*}{$\mathrm{SEM}^{1}$} & \multicolumn{2}{|c|}{$P$-value ${ }^{2}$} \\
\hline & SB & RUM & ESBM & & TRT & Seq \\
\hline $\mathrm{BW}, \mathrm{kg}$ & 720 & 718 & 725 & 4.40 & 0.28 & 0.31 \\
\hline $\mathrm{BCS}$ & 2.83 & 2.86 & 2.80 & 0.09 & 0.71 & 0.75 \\
\hline DMI, $\mathrm{kg} / \mathrm{d}$ & 25.9 & 25.5 & 25.9 & 0.66 & 0.65 & 0.25 \\
\hline DMI, $\%$ of BW & 3.64 & 3.61 & 3.60 & 0.12 & 0.85 & 0.58 \\
\hline
\end{tabular}

${ }^{1}$ Largest SEM.

${ }^{2} \mathrm{TRT}=$ treatment effect; Seq $=$ sequence effect.

\section{Effects on DMI, BW, and BCS}

The DMI, DMI as \% BW, BW, and BCS were not affected by dietary treatments; however, a period effect $(P<0.01)$ was observed for all variables (Table 2$)$. However, this period effect cannot be associated with a single period being different across all these parameters. As expected, the DMI and DMI as \% BW decreased linearly throughout the periods (Supplemental Table S2; https://doi.org/10.3168/jds.2019-16996).

\section{Milk Production and Composition}

The production variables, as well as milk efficiency in terms of milk/DMI and ECM/DMI ratios, are presented in Table 3. A treatment effect was observed for TS $(P<0.01)$, MUN $(P<0.01)$, protein yield $(P=$ $0.04)$, milk/DMI $(P=0.01)$, and ECM/DMI variables, whereas a trend $(P=0.07)$ was observed for milk yield
(Table 3). The treatment effect observed in TS was mainly associated with greater $(P<0.02)$ TS in SB-fed cows in comparison to RUM and ESBM. The MUN was greatest $(P<0.01)$ in SB-fed cows followed by RUM $(P<0.01)$, and ESBM had the lowest $(P<0.01)$ MUN concentrations. The treatment effect observed in protein yield was mainly associated with greater $(P$ $=0.02)$ protein yield in RUM-fed cows in comparison to SB; however, protein yield was similar $(P=0.43)$ between RUM and ESBM cows. The ECM was greater $(P \leq 0.03)$ in RUM and ESBM cows in comparison to SB. The milk efficiency reported as milk/DMI was greater $(P<0.01)$ in RUM-fed cows than SB, whereas milk/DMI in ESBM cows was similar with either SB ( $P$ $=0.07)$ or RUM $(P=0.18)$ cows. Similar to ECM, the milk efficiency as ECM/DMI was greater $(P \leq 0.01)$ in RUM and ESBM cows in comparison to SB. Overall the milk yield followed a similar pattern as protein yield and milk/DMI, where milk yield was greater $(P$

Table 3. Effects of supplementing dairy cows with soybean meal (SB), phytochemicals (RUM), and expeller soybean meal (ESBM) during mid-lactation on production variables

\begin{tabular}{|c|c|c|c|c|c|c|}
\hline \multirow[b]{2}{*}{ Item } & \multicolumn{3}{|c|}{ Treatment } & \multirow[b]{2}{*}{$\mathrm{SEM}^{1}$} & \multicolumn{2}{|c|}{$P$-value ${ }^{2}$} \\
\hline & $\mathrm{SB}$ & RUM & ESBM & & TRT & Seq \\
\hline $\begin{array}{l}\text { Milk, } \mathrm{kg} / \mathrm{d} \\
\text { Milk composition }\end{array}$ & $36.0^{\mathrm{b}}$ & $37.9^{\mathrm{a}}$ & $37.4^{\mathrm{ab}}$ & 0.96 & 0.07 & 0.50 \\
\hline $\begin{array}{l}\text { Fat, } \% \\
\text { Fing composition }\end{array}$ & 3.95 & 3.96 & 3.95 & 0.11 & 0.97 & 0.94 \\
\hline Protein, $\%$ & 3.06 & 3.03 & 3.01 & 0.03 & 0.15 & 0.67 \\
\hline Lactose, \% & 4.93 & 4.90 & 4.91 & 0.03 & 0.37 & 0.91 \\
\hline TS, $\%$ & $11.4^{\mathrm{a}}$ & $11.2^{\mathrm{b}}$ & $11.1^{\mathrm{b}}$ & 0.08 & $<0.01$ & 0.67 \\
\hline MUN, mg/dL & $10.30^{\mathrm{a}}$ & $9.75^{\mathrm{b}}$ & $9.14^{\mathrm{c}}$ & 0.21 & $<0.01$ & 0.92 \\
\hline Log-transformed SCC & 3.47 & 3.55 & 3.47 & 0.14 & 0.52 & 0.44 \\
\hline Milk composition yield & & & & & & \\
\hline Fat, kg/d & 1.43 & 1.50 & 1.49 & 0.05 & 0.31 & 0.79 \\
\hline Protein, $\mathrm{kg} / \mathrm{d}$ & $1.08^{\mathrm{b}}$ & $1.15^{\mathrm{a}}$ & $1.13^{\mathrm{ab}}$ & 0.03 & 0.04 & 0.67 \\
\hline $\mathrm{TS}, \mathrm{kg} / \mathrm{d}$ & 4.11 & 4.17 & 4.13 & 0.15 & 0.95 & 0.62 \\
\hline $\mathrm{ECM}, \mathrm{kg} / \mathrm{d}$ & $37.1^{\mathrm{b}}$ & $39.7^{\mathrm{a}}$ & $39.3^{\mathrm{a}}$ & 1.67 & 0.03 & 0.86 \\
\hline Milk/DMI & $3.07^{\mathrm{b}}$ & $3.28^{\mathrm{a}}$ & $3.19^{\mathrm{ab}}$ & 0.10 & 0.01 & 0.89 \\
\hline $\mathrm{ECM} / \mathrm{DMI}$ & $1.45^{\mathrm{b}}$ & $1.56^{\mathrm{a}}$ & $1.53^{\mathrm{a}}$ & 0.06 & $<0.01$ & 0.74 \\
\hline
\end{tabular}

${ }^{\mathrm{a}-\mathrm{c}}$ Within a row, means without a common superscript are different based on the treatment effect $(P<0.05)$.

${ }^{1}$ Largest SEM.

${ }^{2} \mathrm{TRT}=$ treatment effect; Seq $=$ sequence effect. 
Table 4. Ruminal $\mathrm{pH}, \mathrm{NH}_{3}-\mathrm{N}$, and VFA concentrations of cows supplemented with soybean meal (SB), phytochemicals (RUM), and expeller soybean meal (ESBM)

\begin{tabular}{|c|c|c|c|c|c|c|}
\hline \multirow[b]{2}{*}{ Rumen measure } & \multicolumn{3}{|c|}{ Treatment } & \multirow[b]{2}{*}{$\mathrm{SEM}^{1}$} & \multicolumn{2}{|c|}{$P$-value ${ }^{2}$} \\
\hline & SB & RUM & ESBM & & TRT & Seq \\
\hline $\mathrm{NH}_{3}-\mathrm{N}, \mathrm{mg} / \mathrm{dL}$ & 7.61 & 9.95 & 7.57 & 0.99 & 0.13 & 0.82 \\
\hline Total VFA, $\mathrm{m} M$ & $97.9^{\mathrm{b}}$ & $118.1^{\mathrm{a}}$ & $105.2^{\mathrm{b}}$ & 6.1 & 0.01 & 0.95 \\
\hline \multicolumn{7}{|l|}{ VFA, mol/100 mol } \\
\hline Acetate & $63.7^{\mathrm{b}}$ & $64.0^{\mathrm{b}}$ & $65.2^{\mathrm{a}}$ & 0.53 & 0.01 & 0.22 \\
\hline Propionate & $24.5^{\mathrm{a}}$ & $24.1^{\mathrm{a}}$ & $23.2^{\mathrm{b}}$ & 0.50 & $<0.01$ & 0.40 \\
\hline Butyrate & 9.1 & 9.2 & 8.9 & 0.23 & 0.48 & 0.59 \\
\hline Isovalerate & 1.7 & 1.5 & 1.6 & 0.07 & 0.18 & 0.64 \\
\hline Valerate & $1.1^{\mathrm{ab}}$ & $1.2^{\mathrm{a}}$ & $1.1^{\mathrm{b}}$ & 0.06 & 0.08 & 0.86 \\
\hline Acetate:propionate & $2.62^{\mathrm{b}}$ & $2.67^{\mathrm{b}}$ & $2.83^{\mathrm{a}}$ & 0.08 & $<0.01$ & 0.29 \\
\hline
\end{tabular}

$=0.03)$ in RUM-fed cows than SB, whereas ESBM was similar to RUM $(P=0.52)$ and tended to be greater $(P$ $=0.10)$ than SB-fed cows.

A period effect was observed in all parameters except for fat yield. This consistent effect across most production variables can be associated with a natural decline in milk production as cows progress through lactation, and such decline tends to increase the concentration of solids (e.g., fat, protein, lactose) in milk, which is consistent with our results (Supplemental Table S3; https: //doi.org/10.3168/jds.2019-16996).

\section{Rumen Fermentation}

Rumen fermentation characteristics are presented in Table 4. A treatment effect $(P \leq 0.01)$ was observed for the total VFA and proportions of acetate and propionate, and a trend $(P=0.08)$ for valerate. The effect observed in total VFA was associated with a greater $(P \leq 0.04)$ total VFA in RUM cows in comparison to $\mathrm{SB}$ and ESBM. The acetate was greater $(P \leq 0.01)$ in ESBM in comparison to RUM and SB, whereas propionate was lower $(P \leq 0.01)$ in ESBM than RUM and
SB. The effect observed in valerate was associated with a greater $(P=0.03)$ valerate in RUM than ESBM, whereas SB cows had similar $(P \geq 0.25)$ valerate than RUM and ESBM. A treatment effect $(P<0.01)$ was observed for the acetate to propionate ratio; this ratio was greater $(P \leq 0.01)$ in ESBM cows in comparison to RUM and SB.

\section{Total-Tract Nutrient Digestion}

Total-tract nutrient digestibility is presented in Table 5 . The digestibility of DM, OM, and NDF had a treatment effect $(P \leq 0.01)$, where greater DM $(P \leq 0.04)$ and $\mathrm{OM}(P \leq 0.03)$ digestibility was observed in ESBM cows in comparison to SB and RUM. Lower $(P \leq 0.02)$ NDF digestibility was observed in SB cows in comparison to RUM and ESBM. A trend $(P=0.08)$ for a dietary effect on ADF digestibility was observed, where ESBM cows had greater $(P=0.04)$ ADF digestibility than $\mathrm{SB}$, and $\mathrm{ADF}$ digestibility in RUM was similar to ESBM and SB. A consistent sequence effect $(P \leq 0.01)$ was observed on all digestibility parameters, except for NDF, and such effect can be associated with greater

Table 5. Total-tract digestibility of nutrients in cows supplemented with soybean meal (SB), phytochemicals (RUM), and expeller soybean meal (ESBM)

\begin{tabular}{|c|c|c|c|c|c|c|}
\hline \multirow{2}{*}{$\begin{array}{l}\text { Item, \% } \\
\text { digested }\end{array}$} & \multicolumn{3}{|c|}{ Treatment } & \multirow[b]{2}{*}{$\mathrm{SEM}^{1}$} & \multicolumn{2}{|c|}{$P$-value ${ }^{2}$} \\
\hline & SB & RUM & ESBM & & TRT & Seq \\
\hline$\overline{\mathrm{DM}}$ & $66.1^{\mathrm{b}}$ & $67.7^{\mathrm{b}}$ & $70.1^{\mathrm{a}}$ & 0.79 & $<0.01$ & $<0.01$ \\
\hline $\mathrm{OM}$ & $68.2^{\mathrm{b}}$ & $69.6^{\mathrm{b}}$ & $71.7^{\mathrm{a}}$ & 0.67 & $<0.01$ & $<0.01$ \\
\hline $\mathrm{CP}$ & 64.7 & 66.4 & 67.5 & 1.08 & 0.20 & $<0.01$ \\
\hline $\mathrm{NDF}$ & $58.6^{\mathrm{b}}$ & $62.3^{\mathrm{a}}$ & $61.7^{\mathrm{a}}$ & 0.87 & 0.01 & 0.18 \\
\hline $\mathrm{ADF}$ & $64.0^{\mathrm{b}}$ & $64.2^{\mathrm{ab}}$ & $65.9^{\mathrm{a}}$ & 0.65 & 0.08 & 0.01 \\
\hline
\end{tabular}

$\overline{\mathrm{a}, \mathrm{b}}$ Within a row, means without a common superscript are different based on the treatment effect $(P<0.05)$.

${ }^{1}$ Largest SEM.

${ }^{2} \mathrm{TRT}=$ treatment; Seq $=$ sequence. 
Table 6. Blood biomarkers of metabolism in cows supplemented with soybean meal (SB), phytochemicals (RUM), and expeller soybean meal (ESBM)

\begin{tabular}{|c|c|c|c|c|c|c|}
\hline \multirow[b]{2}{*}{ Item } & \multicolumn{3}{|c|}{ Treatment } & \multirow[b]{2}{*}{$\mathrm{SEM}^{1}$} & \multicolumn{2}{|c|}{$P$-value ${ }^{2}$} \\
\hline & SB & RUM & ESBM & & TRT & Seq \\
\hline Glucose, $\mathrm{mg} / \mathrm{dL}$ & 95.7 & 93.8 & 93.5 & 1.57 & 0.52 & 0.08 \\
\hline Urea, mg/dL & 17.0 & 15.5 & 15.5 & 0.59 & 0.10 & 0.08 \\
\hline Creatinine, $\mu \mathrm{mol} / \mathrm{L}$ & 0.772 & 0.762 & 0.722 & 0.025 & 0.35 & 0.13 \\
\hline $\mathrm{NEFA},{ }^{3} \mathrm{mmol} / \mathrm{L}$ & 0.110 & 0.107 & 0.118 & 0.021 & 0.91 & 0.37 \\
\hline $\mathrm{BHB}, \mathrm{mmol} / \mathrm{L}$ & $0.435^{\mathrm{b}}$ & $0.496^{\mathrm{a}}$ & $0.423^{\mathrm{b}}$ & 0.023 & 0.05 & 0.67 \\
\hline
\end{tabular}

digestibility in cows going through the sequence SBRUM-ESBM during the 3 periods of the Latin square; however, this effect seems to be isolated to total-tract digestibility as it is not present in the rest of the data in this study.

\section{Blood Metabolites}

Blood biomarkers associated with metabolism are presented in Table 6. Among blood biomarkers only BHB was affected $(P=0.05)$ by dietary treatments, where RUM cows had greater $(P \leq 0.05)$ BHB than SB and ESBM. A trend $(P=0.10)$ was observed in urea, which can be mainly associated with SB cows to having greater urea than RUM $(P=0.06)$ and $\operatorname{ESBM}(P=$ $0.07)$. Besides glucose, all parameters had a period effect $(P \leq 0.01)$; however, this effect was not associated with a specific period (Supplemental Table S4; https:/ /doi.org/10.3168/jds.2019-16996).

\section{Abundance of Ruminal Bacteria}

The relative abundance of target bacterial species is presented in Table 7. Selenomonas ruminantium, Succinimonas amylolytica, and Streptococcus bovis were the only bacteria species with an overall treatment effect $(P \leq 0.03)$, which was associated with a consistent lower $(P \leq 0.01)$ abundance of these bacteria in RUM cows in comparison to SB and ESBM.

\section{DISCUSSION}

\section{Effects on DMI, BW, and BCS}

Traditionally tannins have been commonly associated with reductions on feed intake in ruminants primarily due to decreases in palatability (Cooper and OwenSmith, 1985) or astringency (Landau et al., 2000), and these effects have been mainly associated with high concentrations ( $>5 \%$ of diet on DM basis) of tannins

Table 7. Relative abundance (\%) of microbial species in mixed ruminal fluid from Holstein cows supplemented with soybean meal (SB), phytochemicals (RUM), and expeller soybean meal (ESBM)

\begin{tabular}{|c|c|c|c|c|c|c|}
\hline \multirow[b]{2}{*}{ Species $^{1}$} & \multicolumn{3}{|c|}{ Treatment } & \multirow[b]{2}{*}{$\mathrm{SEM}^{2}$} & \multicolumn{2}{|c|}{$P$-value ${ }^{3}$} \\
\hline & $\mathrm{SB}$ & RUM & ESBM & & TRT & Seq \\
\hline Anaerovibrio lipolytica & $1.00 \times 10^{-2}$ & $6.17 \times 10^{-3}$ & $7.30 \times 10^{-3}$ & 0.51 & 0.56 & 0.27 \\
\hline Butyvibrio proteoclasticus & $8.24 \times 10^{-2}$ & $6.99 \times 10^{-2}$ & $9.09 \times 10^{-2}$ & 0.22 & 0.30 & 0.99 \\
\hline Eubacterium ruminantium & $3.52 \times 10^{-2}$ & $3.14 \times 10^{-2}$ & $3.17 \times 10^{-2}$ & 0.26 & 0.79 & 0.57 \\
\hline Fibrobacter succinogenes & $9.91 \times 10^{-2}$ & $1.09 \times 10^{-1}$ & $1.15 \times 10^{-1}$ & 0.20 & 0.66 & 0.21 \\
\hline Megaspheara elsdenii & $9.79 \times 10^{-3}$ & $1.09 \times 10^{-2}$ & $1.16 \times 10^{-2}$ & 0.36 & 0.76 & 0.74 \\
\hline Prevotella bryantii & $1.12 \times 10^{-1}$ & $9.96 \times 10^{-2}$ & $1.28 \times 10^{-1}$ & 0.37 & 0.77 & 0.31 \\
\hline Selenomonas ruminantium & $1.71 \times 10^{-1 \mathrm{a}}$ & $1.56 \times 10^{-2 \mathrm{~b}}$ & $1.73 \times 10^{-1 \mathrm{a}}$ & 0.98 & $<0.01$ & 0.16 \\
\hline Succinimonas amylolytica & $6.28 \times 10^{-3 a}$ & $1.92 \times 10^{-3 \mathrm{~b}}$ & $6.12 \times 10^{-3 a}$ & 0.54 & 0.03 & $<0.01$ \\
\hline Succinivibrio dextrinosolvens & $1.95 \times 10^{-2}$ & $1.58 \times 10^{-2}$ & $3.24 \times 10^{-2}$ & 0.39 & 0.15 & 0.07 \\
\hline Streptococcus bovis & $1.93 \times 10^{-3 \mathrm{a}}$ & $7.15 \times 10^{-4 b}$ & $2.62 \times 10^{-3 a}$ & 0.45 & $<0.01$ & 0.19 \\
\hline
\end{tabular}

${ }^{\mathrm{a}, \mathrm{b}}$ Within a row, means without a common superscript are different based on the treatment effect $(P<0.05)$.

${ }^{1}$ Data were log-transformed before statistics. The SEM associated with log-transformed data are in log scale.

${ }^{2}$ Largest SEM.

${ }^{3} \mathrm{TRT}=$ treatment; Seq $=$ sequence. 
in the diet (McNabb et al., 1996). This is consistent with more recent studies where using tannins at $<5 \%$ inclusion rate in the diet did not have a negative effect on feed intake (Sliwinski et al., 2004; Liu et al., 2013; Henke et al., 2017). However, some have observed reductions in feed intake due to tannin supplementation at 1.8\% (Aguerre et al., 2016) and 3\% (Dschaak et al., 2011) inclusion rates in the diet. In the current study, the RUM pellet was designed to contained $1.5 \%$ phytochemicals, including tannins and Capsicum. In turn, the RUM pellet was offered at $4.16 \%$ of the diet on a DM basis (Table 1), which indicates that the feeding rate of these phytochemicals in the diet represented approximately $0.06 \%$ of the diet on DM basis. Then, this low inclusion rate in comparison to previous studies can be attributed to the lack of negative effects on DMI. In contrast to tannins, Capsicum species have been associated with increased DMI in ruminants (Cardozo et al., 2006; Rodriguez-Prado et al., 2012). However, the lack of response in DMI in the current experiment suggests a low inclusion rate of Capsicum within the RUM pellet, or the effect in DMI observed by Cardozo et al. (2006) and Rodriguez-Prado et al. (2012) in beef heifers is more challenging to be translated into adult lactating dairy cows.

Due to the short-term exposure (30 d in each period) of dairy cows to phytochemicals and coupled with the lack of effect on DMI, it is reasonable to observe no response on BW and BCS (Table 2). In the case of tannins, a lack of response in BW and BCS has been previously observed (Sliwinski et al., 2004; Liu et al., 2013; Aguerre et al., 2016) when feeding greater concentrations of tannins than the current study to dairy cows.

\section{Nutrient Digestibility}

The negative effect of tannins on nutrient digestibility, primarily on proteins, have been commonly associated with the formation of tannin-protein complexes between $\mathrm{pH} 3.5$ and 8.0. However, if these complexes are not dissociated postruminally in the abomasum ( $\mathrm{pH} 2.5-3.0$ ) or duodenum ( $\mathrm{pH} \sim 8.0$ ), this will reduce the digestibility and absorption of proteins (Frutos et al., 2004). This detrimental effect on nutrient digestibility has been reported in ruminants not only in $\mathrm{CP}$ (Beauchemin et al., 2007) but also in DM, OM, NDF, and ADF (Aguerre et al., 2016; Henke et al., 2017). In contrast to these results, tannins contained in RUM diet did not affect nutrient digestibility when compared with SB, except an increased digestibility in NDF (Table 5). While this lack of response on digestibility can be associated with the low inclusion rate of tannins $(0.06 \%)$ in the RUM diet, the effect on NDF digest- ibility remains unclear. Feeding Capsicum oleoresin to lactating dairy cows did not produce any effect on total-tract digestibility (Oh et al., 2015). Interestingly, when a rumen-protected Capsicum extract was fed to lactating dairy cows, a linear increase in total-tract digestibility was observed in $\mathrm{DM}, \mathrm{OM}$, and $\mathrm{CP}$ (Oh et al., 2017b). Also, this effect was associated with stimulation of digestive enzymes in the lower gut by capsaicin.

\section{Milk Production, Composition, and N Efficiency}

Although several studies have indicated that tannins do not have an effect on milk production in dairy cows (Liu et al., 2013; Aguerre et al., 2016; Gerlach et al., 2018), Turner et al. (2005) and Anantasook et al. (2015) reported an overall increase in milk production of 3.84 and $1.3 \mathrm{~kg} / \mathrm{d}$, respectively. Although this agrees with the $1.7 \mathrm{~kg} / \mathrm{d}$ increase in milk production observed in cows supplemented with RUM in comparison to SB (Table 3), Turner et al. (2005) and Anantasook et al. (2015) used different sources of tannins [i.e., birdsfoot trefoil (Lotus corniculatus) and rain tree (Samanea saman), respectively]. In contrast to these studies, the RUM treatment contained a mixture of condensed (i.e., quebracho) and hydrolyzable (i.e., quercus) tannins. The inclusion rate of tannins may play a role in milk production, as Aguerre et al. (2016) reported a lack of effect on milk production while feeding a tannin mixture at $0.45,0.9$, and $1.8 \%$ of diet DM, which were higher concentrations than the $0.06 \%$ used in the RUM diet. Milk yield responses to Capsicum species supplementation are variable; for instance, Tager and Krause (2011) observed no effect on milk yield, whereas Oh et al. (2013) observed an approximately $2 \mathrm{~kg} / \mathrm{d}$ decrease in milk yield when performing $2 \mathrm{~g} / \mathrm{d}$ abomasal infusions of Capsicum oleoresin on lactating dairy cows. In contrast, Oh et al. (2015) observed a positive quadratic effect when supplementing Capsicum oleoresin from 0 to $1,000 \mathrm{mg} / \mathrm{d}$ in dairy cows, and $\mathrm{Oh}$ et al. (2017b) observed an increase in milk yield when supplementing lactating cows with $>100 \mathrm{mg} / \mathrm{d}$ of rumen-protected Capsicum oleoresin. Taken together, this suggests that a clear effect on milk yield by tannins, Capsicum, or their combination remains to be elucidated. This task is particularly challenging when there are many sources of tannins in the condensed or hydrolyzable forms, whereas data on the compartmentalized effects of Capsicum in the rumen and the lower gut are lacking.

Although greater TS in milk were observed in SB in comparison to RUM and ESBM diets (Table 3), these differences were $\leq 0.23 \%$, indicating a low biological significance, especially because this effect was not translated into greater yield of TS in SB compared with other treatments. Similar to our results, a consistent 
lack of tannin effect on total milk solids was observed in prior studies (Turner et al., 2005; Anantasook et al., 2015; Aguerre et al., 2016). Besides TS, milk components on a percentage basis were not affected by dietary treatments; however, we observed a $70 \mathrm{~g} / \mathrm{d}$ increase in protein yield between RUM cows compared with SB. Although this effect in protein yield might be considered negligible, it contrasts with no effects (Turner et al., 2005; Dschaak et al., 2011; Liu et al., 2013) or negative effects on milk protein (Aguerre et al., 2016; Henke et al., 2017; Gerlach et al., 2018) observed in previous studies feeding tannins. To the authors' knowledge, Anantasook et al. (2015) was the only study reporting a $0.2 \%$ increase in milk protein when supplementing dairy cows with condensed tannins from rain tree $(S$. saman). Despite the attributed effect of tannins to protect protein from ruminal degradation (Makkar, 2003), this effect seems not to be translated into milk protein yield. The latter has been argued to be related to a low postruminal dissociation of the tannin-protein complexes once they reach the acidic $\mathrm{pH}$ of the abomasum (Gerlach et al., 2018) or reductions in digestibility of important AA such as Met and Cys by tannin supplementation (Wang et al., 2009). Similar to tannins, Capsicum species have not been associated with an effect on milk components (Tager and Krause, 2011; Oh et al., 2013, 2017a,b) in dairy cows with the exception of Oh et al. (2015), where an increase in milk fat yield was reported. Therefore, the increased milk protein yield observed in the current experiment is more likely to be related to a tannin with an effect in the rumen.

In ruminants, dietary $\mathrm{CP}$ is degraded by ruminal microorganisms into peptides, $\mathrm{AA}$, and $\mathrm{NH}_{3}-\mathrm{N}$ (Bach et al., 2005). Then, the excess $\mathrm{NH}_{3}-\mathrm{N}$ is absorbed into the rumen wall and bloodstream, and it will eventually reach the liver for conversion into urea (Harmeyer and Martens, 1980), and this urea can be either excreted in urine and milk or delivered into the rumen as part of the $\mathrm{N}$ recycling mechanism in ruminants (Colmenero and Broderick, 2006). Because of this mechanism, concentrations of urea in blood, urine, and milk are highly associated with $\mathrm{N}$ recycling and ruminal protein degradation. In the current study we observed a consistent decreased in MUN and a trend $(P=0.10)$ for decreased blood urea in RUM and ESBM cows in comparison to $\mathrm{SB}$, which is in agreement with a lower protein ruminal degradation, and even though $\mathrm{NH}_{3}-\mathrm{N}$ was not affected by dietary treatments (Table 4), it is indicative of an improvement in $\mathrm{N}$ efficiency. Similar effects of tannins on MUN and BUN have been previously reported (Sliwinski et al., 2004; Dschaak et al., 2011; Aguerre et al., 2016), which represents a consistent effect of tannin supplementation in ruminants. Capsicum species seem to exert no effect on $\mathrm{N}$ utilization in lactating dairy cows, primarily based on MUN and $\mathrm{NH}_{3}-\mathrm{N}$ data (Oh et al., 2013; Oh et al., 2015, 2017b).

In the current experiment, dietary effects on efficiency were not only limited to $\mathrm{N}$ but also greater feed efficiency in terms of milk/DMI and ECM/DMI were observed in RUM cows compared with SB, and this effect is in agreement with prior studies when feeding tannins to lactating dairy cows (Dschaak et al., 2011; Aguerre et al., 2016). Interestingly, previous data reporting improved feed efficiency with tannin supplementation have been mainly associated with lower DMI due, in part, to palatability issues rather than increased in milk yield (Dschaak et al., 2011; Aguerre et al., 2016), which contrasts with our results, where feed efficiency was primarily driven by greater milk yield in RUM cows (Table 3). This lack of effect on DMI could be related to the lower inclusion rate of tannins and Capsicum in the RUM diet. Limited data are available on the effects of Capsicum species on milk efficiency in dairy cows. However, Oh et al. (2013, 2015) observed no effects of Capsicum supplementation on milk efficiency in dairy cows, whereas Oh et al. (2017b) reported a trend for an increase in milk efficiency when cows were fed a rumenprotected Capsicum supplement.

\section{Rumen Fermentation Characteristics}

The rumen $\mathrm{pH}$ of dairy cows is commonly unaffected by tannin supplementation (Sliwinski et al., 2002; Dschaak et al., 2011; Anantasook et al., 2015), whereas $\mathrm{NH}_{3}-\mathrm{N}$ is consistently decreased (Sliwinski et al., 2002; Dschaak et al., 2011; Aguerre et al., 2016). Therefore, the lack of response observed in $\mathrm{NH}_{3}-\mathrm{N}$ when feeding RUM can be attributed to the low inclusion rate of tannins in this diet (Table 4). However, this hypothesis cannot be confirmed because this low level of tannin supplementation has never been investigated before in dairy cows. Tannins commonly do not exert any effect on total VFA concentration (Sliwinski et al., 2002; Benchaar et al., 2008; Aguerre et al., 2016); however, we observed a greater total VFA concentration in cows fed the RUM diet in comparison to SB and ESBM. Studies have observed tannin effects on specific VFA; for instance, tannin supplementation to dairy cows has been reported to increase propionate concentration while decreasing acetate (Waghorn et al., 1994; Makkar, 2003; Anantasook et al., 2015); however, this effect has not been consistent throughout the literature. Capsicum species have been reported to increase total VFA concentration in vitro at low $\mathrm{pH}$ concentrations (i.e., 5.5 vs. 7.0) while increasing the proportions of propionate and decreasing acetate (Cardozo et al., 2005). Similarly, in vivo experiments feeding Capsicum to beef heifers under a high concentrate diet have 
observed an increase in total VFA (Rodriguez-Prado et al., 2012) while decreasing acetate (Cardozo et al., 2006). In the current study, the increase in total VFA concentration in the RUM diet was not associated with a single VFA (e.g., acetate, propionate, and so on) on a percentage basis. However, a greater yield of each VFA on an $m M$ basis could be attributed the greater total VFA concentration in the RUM diet. Then, this effect could partially explain the improvements in milk yield and components observed in cows fed the RUM diet.

\section{Ruminal Bacteria Populations}

The effects observed in ruminal bacterial populations represent the rumen fluid fraction, which contains small nondegraded feed particles, metabolites, microbial remnants, and this fraction is considered to have less abundance of bacterial populations than that of bacteria adherent to large particles of feeds (Kong et al., 2010). In terms of bacterial diversity, Ji et al. (2017) observed that the liquid fraction had similar bacterial diversity with rumen digesta and solid fraction, but warned that a bias in bacterial distribution should be considered when samples of liquid fraction are used to assess dietary effects on rumen bacterial community. The latter bias was mainly associated with significant changes in dietary composition such as high fiber and high energy diets; however, based on the similar basal diet used in the current study it could be argued that such bias was less significant.

Selenomonas ruminantium has been commonly associated with starch digestion while producing lactic, acetic, and propionic acids (Zhou et al., 2015). Also, $S$. ruminantium has been consistently reported to be resistant to tannins (Odenyo et al., 2001; Bishop et al., 2004; Krause et al., 2004); in fact, it has been reported that this bacterium can metabolize tannins or even use them as an energy source (Nelson et al., 1998; Goel et al., 2005). In the current experiment, a lower relative abundance of $S$. ruminantium was observed in the RUM diet in comparison to other diets. This effect is contradictory to previous data reporting a relative resistance of $S$. ruminantium to tannins and even S. ruminantium utilizing tannins as an energy source. While this effect could be associated with the presence of Capsicum in the RUM diet, there is no available data on the effects of Capsicum species on S. ruminantium, therefore, this effect remains to be elucidated. Succinimonas amylolytica has been related to SARA conditions in dairy goats, where goats undergoing a SARA condition had a significant increase in S. amylolytica in comparison to a control group (Li et al., 2014). Interestingly, studies on residual feed intake (feed efficiency independent of BW and milk yield) in beef cattle and early lactation dairy cows have consistently observed a low abundance of $S$. amylolytica in the most efficient animals (Elolimy et al., 2018a,b). Shabat et al. (2016) used a genomic analysis in which microbiome reads were aligned to the known gut microbial genomes and observed an enrichment of S. amylolytica in inefficient cow microbiomes; however, this effect did not reach statistical significance. These data partially agree with our results, where cows fed the RUM diet had the lowest abundance of $S$. amylolytica (Table 7) coupled with a greater milk efficiency than SB cows, but this effect does not explain the similar efficiency between RUM and ESBM cows (Table 3). Perhaps, a greater delivery of RUP in the ESBM diet allowed cows to have an improved milk efficiency comparable to RUM. The inhibitory effects of tannins on Streptococcus bovis have been well documented (Jones et al., 1994; O'Donovan and Brooker, 2001; Min et al., 2002). This gram-positive bacterium is responsible for rapidly fermenting starch and produce lactic acid as the end product of fermentation (Zhou et al., 2015). Similar to $S$. amylolytica, S. bovis, as a starch digester, have been observed to increase during SARA conditions in dairy cows (Khafipour et al., 2009). The decreased abundance of $S$. bovis in RUM diet is consistent with prior data indicating this bacterium is sensitive to tannins. Another similarity between S. amylolytica and $S$. bovis is that these bacteria were observed in lower abundance in the rumen of the most efficient cows during the peripartal period (Elolimy et al., 2018b). This further confirms the notion that a combination of tannins and Capsicum will inhibit bacteria that promote low efficiency in ruminants such as $S$. amylolytica and $S$. bovis. However, the mechanism by which these phytochemicals (i.e., tannins and Capsicum) affect $S$. ruminantium and S. amylolytica remains unknown. Although the effects on S. ruminantium and S. amylolytica provide an explanation for the results in this study, their abundance in rumen fluid was relatively low. Therefore, future research analyzing a complete picture of the microbiome could shed light on other bacteria with a larger abundance being altered by tannins and Capsicum, which could provide further mechanisms to explain the connection between the rumen microbiome alterations and the results observed in milk yield and efficiency in this study.

\section{CONCLUSIONS}

Our data described the responses on performance parameters and rumen fermentation characteristics when dairy cows were fed a combination of tannin mixture (i.e., condense and hydrolyzable) and Capsicum in comparison to ESBM and SB. These data suggest that the synchronized feeding of phytochemicals that 
promote greater RUP along with a high-quality protein source (e.g., soybean meal) allowed cows to produce similar milk yield at the same efficiency as cows fed ESBM. These phytochemicals improved total VFA concentration as well as propionate by reducing or inhibiting the abundance of bacteria associated with low feed efficiency in ruminants. The lower abundance of $S$. ruminantium is inconsistent with prior data on tannins and presumably is caused by the inclusion of Capsicum or the interaction between this and tannins in the RUM diet.

\section{ACKNOWLEDGMENTS}

The authors gratefully acknowledge Groupe CCPA (Janzé, France) and the South Dakota Agricultural Experiment Station, Brookings (project no. SD00H612-16), for financial support for this research. We gratefully acknowledge help from Peter Linke and the staff at the South Dakota State University Dairy Research and Training Facility (Brookings) for animal care and handling.

\section{REFERENCES}

Abdelmegeid, M. K., A. A. Elolimy, Z. Zhou, V. Lopreiato, J. C. McCann, and J. J. Loor. 2018. Rumen-protected methionine during the peripartal period in dairy cows and its effects on abundance of major species of ruminal bacteria. J. Anim. Sci. Biotechnol. 9:17.

Aguerre, M. J., M. C. Capozzolo, P. Lencioni, C. Cabral, and M. A. Wattiaux. 2016. Effect of quebracho-chestnut tannin extracts at 2 dietary crude protein levels on performance, rumen fermentation, and nitrogen partitioning in dairy cows. J. Dairy Sci. 99:44764486 .

al-Delaimy, K. S., and S. H. Ali. 1970. Antibacterial action of vegetable extracts on the growth of pathogenic bacteria. J. Sci. Food Agric. 21:110-112.

Anantasook, N., M. Wanapat, A. Cherdthong, and P. Gunun. 2015. Effect of tannins and saponins in Samanea saman on rumen environment, milk yield and milk composition in lactating dairy cows. J. Anim. Physiol. Anim. Nutr. (Berl.) 99:335-344.

Bach, A., S. Calsamiglia, and M. D. Stern. 2005. Nitrogen metabolism in the rumen. J. Dairy Sci. 88(Suppl 1):E9-E21.

Beauchemin, K. A., S. M. McGinn, T. F. Martinez, and T. A. McAllister. 2007. Use of condensed tannin extract from quebracho trees to reduce methane emissions from cattle. J. Anim. Sci. 85:1990-1996.

Benchaar, C., T. A. McAllister, and P. Y. Chouinard. 2008. Digestion, ruminal fermentation, ciliate protozoal populations, and milk production from dairy cows fed cinnamaldehyde, quebracho condensed tannin, or Yucca schidigera saponin extracts. J. Dairy Sci. 91:4765-4777

Bishop, R., M. Obura, D. Odongo, and A. Odenyo. 2004. Specific PCR assay for a tannin-tolerant Selenomonas ruminantium isolate, derived from helicase coding sequences. Appl. Environ. Microbiol. 70:3180-3182.

Calsamiglia, S., M. Busquet, P. W. Cardozo, L. Castillejos, and A. Ferret. 2007. Invited review: Essential oils as modifiers of rumen microbial fermentation. J. Dairy Sci. 90:2580-2595.

Cardozo, P. W., S. Calsamiglia, A. Ferret, and C. Kamel. 2005. Screening for the effects of natural plant extracts at different $\mathrm{pH}$ on in vitro rumen microbial fermentation of a high-concentrate diet for beef cattle. J. Anim. Sci. 83:2572-2579.
Cardozo, P. W., S. Calsamiglia, A. Ferret, and C. Kamel. 2006. Effects of alfalfa extract, anise, capsicum, and a mixture of cinnamaldehyde and eugenol on ruminal fermentation and protein degradation in beef heifers fed a high-concentrate diet. J. Anim. Sci $84: 2801-2808$

Cichewicz, R. H., and P. A. Thorpe. 1996. The antimicrobial properties of chile peppers (Capsicum species) and their uses in Mayan medicine. J. Ethnopharmacol. 52:61-70.

Colmenero, J. J., and G. A. Broderick. 2006. Effect of dietary crude protein concentration on milk production and nitrogen utilization in lactating dairy cows. J. Dairy Sci. 89:1704-1712.

Cooper, S. M., and N. Owen-Smith. 1985. Condensed tannins deter feeding by browsing ruminants in a South African savanna. Oecologia 67:142-146.

Dschaak, C. M., C. M. Williams, M. S. Holt, J. S. Eun, A. J. Young, and B. R. Min. 2011. Effects of supplementing condensed tannin extract on intake, digestion, ruminal fermentation, and milk production of lactating dairy cows. J. Dairy Sci. 94:2508-2519.

Elolimy, A. A., M. K. Abdelmegeid, J. C. McCann, D. W. Shike, and J. J. Loor. 2018a. Residual feed intake in beef cattle and its association with carcass traits, ruminal solid-fraction bacteria, and epithelium gene expression. J. Anim. Sci. Biotechnol. 9:67.

Elolimy, A. A., J. M. Arroyo, F. Batistel, M. A. Iakiviak, and J. J. Loor. 2018b. Association of residual feed intake with abundance of ruminal bacteria and biopolymer hydrolyzing enzyme activities during the peripartal period and early lactation in Holstein dairy cows. J. Anim. Sci. Biotechnol. 9:43.

Fliegerova, K., I. Tapio, A. Bonin, J. Mrazek, M. L. Callegari, P. Bani, A. Bayat, J. Vilkki, J. Kopecny, K. J. Shingfield, F. Boyer, E. Coissac, P. Taberlet, and R. J. Wallace. 2014. Effect of DNA extraction and sample preservation method on rumen bacterial population. Anaerobe 29:80-84.

Frutos, P., G. Hervás, F. J. Giráldez, and A. R. Mantecón. 2004. Review: Tannins and ruminant nutrition. Span. J. Agric. Res. 2:191-202.

Gerlach, K., M. Pries, E. Tholen, A. J. Schmithausen, W. Buscher, and K. H. Sudekum. 2018. Effect of condensed tannins in rations of lactating dairy cows on production variables and nitrogen use efficiency. Animal 12:1847-1855.

Goel, G., A. K. Puniya, C. N. Aguilar, and K. Singh. 2005. Interaction of gut microflora with tannins in feeds. Naturwissenschaften 92:497-503.

Harmeyer, J., and H. Martens. 1980. Aspects of urea metabolism in ruminants with reference to the goat. J. Dairy Sci. 63:1707-1728.

Henke, A., U. Dickhoefer, E. Westreicher-Kristen, K. Knappstein, J. Molkentin, M. Hasler, and A. Susenbeth. 2017. Effect of dietary Quebracho tannin extract on feed intake, digestibility, excretion of urinary purine derivatives and milk production in dairy cows. Arch. Anim. Nutr. 71:37-53.

Huhtanen, P., and A. N. Hristov. 2009. A meta-analysis of the effects of dietary protein concentration and degradability on milk protein yield and milk N efficiency in dairy cows. J. Dairy Sci. 92:3222-3232.

Ji, S., H. Zhang, H. Yan, A. Azarfar, H. Shi, G. Alugongo, S. Li, Z. Cao, and Y. Wang. 2017. Comparison of rumen bacteria distribution in original rumen digesta, rumen liquid and solid fractions in lactating Holstein cows. J. Anim. Sci. Biotechnol. 8:16.

Jones, G. A., T. A. McAllister, A. D. Muir, and K. J. Cheng. 1994. Effects of sainfoin (Onobrychis viciifolia Scop.) condensed tannins on growth and proteolysis by four strains of ruminal bacteria. Appl. Environ. Microbiol. 60:1374-1378.

Khafipour, E., S. Li, J. C. Plaizier, and D. O. Krause. 2009. Rumen microbiome composition determined using two nutritional models of subacute ruminal acidosis. Appl. Environ. Microbiol. 75:7115-7124.

Kong, Y., R. Teather, and R. Forster. 2010. Composition, spatial distribution, and diversity of the bacterial communities in the rumen of cows fed different forages. FEMS Microbiol. Ecol. 74:612-622.

Krause, D. O., W. J. Smith, and C. S. McSweeney. 2004. Use of community genome arrays (CGAs) to assess the effects of Acacia angustissima on rumen ecology. Microbiology 150:2899-2909. 
Landau, S., A. Perevolotsky, D. Bonfil, D. Barkai, and N. Silanikove. 2000. Utilization of low quality resources by small ruminants in Mediterranean agro-pastoral systems: The case of browse and aftermath cereal stubble. Livest. Prod. Sci. 64:39-49.

Li, F., Y. Cao, N. Liu, X. Yang, J. Yao, and D. Yan. 2014. Subacute ruminal acidosis challenge changed in situ degradability of feedstuffs in dairy goats. J. Dairy Sci. 97:5101-5109.

Liu, H. W., D. W. Zhou, and K. Li. 2013. Effects of chestnut tannins on performance and antioxidative status of transition dairy cows. J. Dairy Sci. 96:5901-5907.

Maeda, H., C. Fujimoto, Y. Haruki, T. Maeda, S. Kokeguchi, M. Petelin, H. Arai, I. Tanimoto, F. Nishimura, and S. Takashiba. 2003. Quantitative real-time PCR using TaqMan and SYBR Green for Actinobacillus actinomycetemcomitans, Porphyromonas gingivalis, Prevotella intermedia, tetQ gene and total bacteria. FEMS Immunol. Med. Microbiol. 39:81-86.

Makkar, H. P. S. 2003. Effects and fate of tannins in ruminant animals, adaptation to tannins, and strategies to overcome detrimental effects of feeding tannin-rich feeds. Small Rumin. Res. 49:241-256.

Manthey, A. K., J. L. Anderson, and G. A. Perry. 2016. Feeding distillers dried grains in replacement of forage in limit-fed dairy heifer rations: Effects on growth performance, rumen fermentation, and total-tract digestibility of nutrients. J. Dairy Sci. 99:7206-7215.

McNabb, W. C., G. C. Waghorn, J. S. Peters, and T. N. Barry. 1996. The effect of condensed tannins in Lotus pedunculatus on the solubilization and degradation of ribulose-1,5-bisphosphate carboxylase (EC 4.1.1.39; Rubisco) protein in the rumen and the sites of Rubisco digestion. Br. J. Nutr. 76:535-549.

Min, B. R., G. T. Attwood, K. Reilly, W. Sun, J. S. Peters, T. N. Barry, and W. C. McNabb. 2002. Lotus corniculatus condensed tannins decrease in vivo populations of proteolytic bacteria and affect nitrogen metabolism in the rumen of sheep. Can. J. Microbiol. 48:911-921.

Nelson, K. E., M. L. Thonney, T. K. Woolston, S. H. Zinder, and A. N. Pell. 1998. Phenotypic and phylogenetic characterization of ruminal tannin-tolerant bacteria. Appl. Environ. Microbiol. 64:3824-3830

NRC. 2001. Nutrient Requirements of Dairy Cattle. Vol. 7th. Natl. Acad. Press, Washington, DC.

O'Donovan, L., and J. D. Brooker. 2001. Effect of hydrolysable and condensed tannins on growth, morphology and metabolism of Streptococcus gallolyticus (S. caprinus) and Streptococcus bovis. Microbiology 147:1025-1033.

Odenyo, A. A., R. Bishop, G. Asefa, R. Jamnadass, D. Odongo, and P. Osuji. 2001. Characterization of tannin-tolerant bacterial isolates from East African ruminants. Anaerobe 7:5-15.

Oh, J., F. Giallongo, T. Frederick, J. Pate, S. Walusimbi, R. J. Elias, E. H. Wall, D. Bravo, and A. N. Hristov. 2015. Effects of dietary Capsicum oleoresin on productivity and immune responses in lactating dairy cows. J. Dairy Sci. 98:6327-6339.

Oh, J., M. Harper, F. Giallongo, D. M. Bravo, E. H. Wall, and A. N. Hristov. 2017a. Effects of rumen-protected Capsicum oleoresin on immune responses in dairy cows intravenously challenged with lipopolysaccharide. J. Dairy Sci. 100:1902-1913.

Oh, J., M. Harper, F. Giallongo, D. M. Bravo, E. H. Wall, and A. N. Hristov. 2017b. Effects of rumen-protected Capsicum oleoresin on productivity and responses to a glucose tolerance test in lactating dairy cows. J. Dairy Sci. 100:1888-1901.
Oh, J., A. N. Hristov, C. Lee, T. Cassidy, K. Heyler, G. A. Varga, J. Pate, S. Walusimbi, E. Brzezicka, K. Toyokawa, J. Werner, S. S. Donkin, R. Elias, S. Dowd, and D. Bravo. 2013. Immune and production responses of dairy cows to postruminal supplementation with phytonutrients. J. Dairy Sci. 96:7830-7843.

Oh, J., E. H. Wall, D. M. Bravo, and A. N. Hristov. 2017c. Hostmediated effects of phytonutrients in ruminants: A review. J. Dairy Sci. 100:5974-5983.

Potts, S. B., M. Shaughness, and R. A. Erdman. 2017. The decline in digestive efficiency of US dairy cows from 1970 to 2014. J. Dairy Sci. 100:5400-5410

Raun, N. S., and W. Burroughs. 1962. Suction strainer technique in obtaining rumen fluid samples from intact lambs. J. Anim. Sci. 21:454-457.

Rodriguez-Prado, M., A. Ferret, J. Zwieten, L. Gonzalez, D. Bravo, and S. Calsamiglia. 2012. Effects of dietary addition of capsicum extract on intake, water consumption, and rumen fermentation of fattening heifers fed a high-concentrate diet. J. Anim. Sci. 90:1879-1884.

Schwab, C. G., and G. A. Broderick. 2017. A 100-Year Review: Protein and amino acid nutrition in dairy cows. J. Dairy Sci. 100:1009410112.

Shabat, S. K., G. Sasson, A. Doron-Faigenboim, T. Durman, S. Yaacoby, M. E. Berg Miller, B. A. White, N. Shterzer, and I. Mizrahi. 2016. Specific microbiome-dependent mechanisms underlie the energy harvest efficiency of ruminants. ISME J. 10:2958-2972.

Sliwinski, B. J., M. Kreuzer, F. Sutter, A. Machmuller, and H. R. Wettstein. 2004. Performance, body nitrogen conversion and nitrogen emission from manure of dairy cows fed diets supplemented with different plant extracts. J. Anim. Feed Sci. 13:73-91.

Sliwinski, B. J., C. R. Soliva, A. Machmuller, and M. Kreuzer. 2002. Efficacy of plant extracts rich in secondary constituents to modify rumen fermentation. Anim. Feed Sci. Technol. 101:101-114.

Tager, L. R., and K. M. Krause. 2011. Effects of essential oils on rumen fermentation, milk production, and feeding behavior in lactating dairy cows. J. Dairy Sci. 94:2455-2464.

Turner, S.-A., G. C. Waghorn, S. L. Woodward, and N. A. Thomson. 2005. Condensed tannins in birdsfoot trefoil (Lotus corniculatus) affect the detailed composition of milk from dairy cows. Proc. N.Z Soc. Anim. Prod. 65:283-289.

Waghorn, G. C., I. D. Shelton, W. C. McNabb, and S. N. McCutcheon. 1994. Effects of condensed tannins in Lotus pedunculatus on its nutritive value for sheep. 2. Nitrogenous aspects. J. Agric. Sci 123:109-119.

Wang, Y., G. C. Waghorn, W. C. McNabb, T. N. Barry, M. J. Hedley, and I. D. Shelton. 2009. Effect of condensed tannins in Lotus corniculatus upon the digestion of methionine and cysteine in the small intestine of sheep. J. Agric. Sci. 127:413-421.

Zhou, M., Y. Chen, and L. L. Guan. 2015. Rumen bacteria. Pages 79-95 in Rumen Microbiology: From Evolution to Revolution. A. Puniya, R. Singh, and D. Kamra, ed. Springer, New Delhi, India.

\section{ORCIDS}

J. Halfen (๑) https://orcid.org/0000-0002-1317-1322

J. L. Anderson @ (ํ) https://orcid.org/0000-0001-7590-0749

J. S. Osorio @ https://orcid.org/0000-0001-6192-0917 